\title{
A AUTOCOMPREENSÃO ÉTICA DA ESPÉCIE E O FUTURO DA NATUREZA HUMANA SEGUNDO HABERMAS. SERIA A EUGENIA UM DIREITO?
}

\author{
THE ETHICS SELF-UNDERSTANDING OF THE SPECIES AND THE FUTURE OF THE HUMAN \\ NATURE SECOND HABERMAS. WOULD BE THE EUGENIA A RIGHT?
}

Alexandre Paludo Bressiani: Paulo César Nodari"

\begin{abstract}
Resumo: Com o progresso e os avanços científicos em muitas áreas do saber, a ciência e a técnica, além de proporcionarem a ampliação considerável no horizonte da liberdade e da autonomia, provocam uma espécie de "encantamento da natureza interna". No contexto eminentemente cientificizado e tecnicizado hodierno, neste trabalho objetivou-se realizar um estudo acerca do futuro da natureza humana em Habermas, a partir do texto: O futuro da natureza humana. A presente pesquisa orienta-se pelo método analítico-interpretativo e está dividida em dois momentos. Em um primeiro momento, buscou-se questionar e identificar como e em que medida a eugenia liberal poderia suscitar questões referentes à ética de espécie, isto é, poderia afetar a autocompreensão normativa de sujeitos que agem de forma livre, autônoma e responsável. Em um segundo momento, pretendeu-se apresentar a compreensão de natureza humana envolvida na argumentação habermasiana por conta da complexidade e relevância do tema no debate da eugenia liberal, a fim de questionar se esta poderia vir a tornar-se, inclusive, um direito de todos.
\end{abstract}

Palavras-chave: Habermas. Ciência. Autocompreensão. Ética da espécie. Natureza humana.
Abstract: With the progress and scientific advances in many areas of knowledge, science and technology, besides providing a considerable expansion on the horizon of freedom and autonomy, cause a kind of "enchantment of internal nature". In eminently cientificized and technicized today's context, this paper aims to conduct a study around the future of human nature in Habermas from the text: The Future of Human Nature. This research is guided by the analytical and interpretive method and is divided into two parts. At first, it seeks to ask and identify how and in what extent the liberal eugenics could raise related questions about ethics of species, it means that could affect the rules of self subjects who act in a free, autonomous and responsible. And in a second step, it is intended to provide an understanding of human nature involved in Habermas's argument because of the complexity and importance of the topic in the debate of liberal eugenics, in order to question the liberal eugenics would hopefully become even a right for everyone to use and enjoy.

Keywords: Habermas. Science. Self-understanding. Ethics of the species. Human nature. de Minas Gerais; Professor do Programa de Mestrado Acadêmico em Filosofia na Universidade de Caxias do Sul; Rua Francisco Getúlio Vargas, 1130, Petrópolis, 95020-972, Caxias do Sul, Rio Grande do Sul, Brasil ; paulocesarnodari@hotmail.com 


\section{Introdução}

Situado no contexto cientificizado e tecnicizado atual, no presente artigo objetivou-se realizar um estudo acerca do futuro da natureza humana em Habermas, a partir do texto: O futuro da natureza humana, orientando-se pelo método analítico-interpretativo. $\bigcirc$ artigo está dividido em duas partes fundamentalmente. Em um primeiro momento, buscou-se questionar e identificar como a eugenia liberal poderia suscitar questões referentes à ética de espécie, ou seja, em que medida poderia afetar a autocompreensão normativa de sujeitos que agem de forma livre, autônoma e responsável. Em um segundo momento, pretendeu-se apresentar a compreensão de natureza humana envolvida na argumentação habermasiana, considerando, justamente, a complexidade e a relevância do tema para o debate da eugenia liberal em nosso tempo atual, objetivando questionar se a eugenia liberal poderia vir a tornar-se, inclusive, um direito de todos de poder escolher.

Habermas constata que os avanços da engenharia genética e as novas formas de intervenção médica podem comprometer significativamente a autocompreensão normativa da espécie humana. Esse novo tipo de técnica aplicada à medicina reprodutiva pode ocasionar um deslocamento iminente na moral por conta dos avanços e progresso da engenharia genética nesse primeiro quartel de século XXI. Vislumbra-se como iminente a mudança no limite entre o que é considerado "dado natural" e o que se pode denominar produzido de "maneira artificial", ou seja, entre a sorte natural e a liberdade de escolha, podendo, por conseguinte, ocasionar um abalo a alguns dos aspectos cruciais da moralidade convencional.

\section{Autocompreensão ética da espécie}

A transposição do atual limite entre o concedido pela natureza e o disponível ao homem pela medicina genética altera significativamente a autocompreensão moral? Os pressupostos normativos da autocompreensão moderna estão justificados pela referência de seres humanos que agem como livres e iguais. Por meio da engenharia genética, o espaço de intervenção humana tem papel relevante na formação da própria identidade do homem no seu conjunto e individualidade, uma vez que ela pode pôr em xeque o autoentendimento dele enquanto membro da espécie humana. Conforme Feldhaus (2011, p. 29), é essa a ideia que Habermas entende por moralização da natureza humana, ou seja, uma determinada forma de autocompreensão ética da espécie. Essa é a autocompreensão que está diretamente relacionada com a forma como o homem concebe a si mesmo como pertencente a uma espécie.

O debate filosófico atual em torno da permissibilidade do diagnóstico genético de pré-implantação, ${ }^{1}$ examinado mais ampla e detalhadamente, toca no status moral do embrião. A eugenia

\footnotetext{
1 Conforme Song (2005, p. 28-29): "O diagnóstico genético de pré-implantação é uma técnica que representa um auge de desenvolvimentos nas tecnologias reprodutiva e genética. É um procedimento por meio do qual embriões criados fora do corpo podem passar por uma triagem para determinados defeitos genéticos antes de serem implantados no útero. Sua principal utilização até o momento tem sido auxiliar os que desejam evitar transmitir um gene deletério a seus filhos, quer pelo teste direto para uma doença genética em particular, quer pela determinação do sexo de um embrião (nos casos em que a doença é
} 
liberal, analisada por Habermas (2010, p. 44), efetua uma polarização na discussão, quando se olha a vida humana pré-pessoal. Afirma ele:

Nessa controvérsia, fracassa toda a tentativa de alcançar uma descrição ideologicamente neutra e, portanto, sem prejulgamentos, do status moral da vida humana prematura, que seja aceitável para todos os cidadãos de uma sociedade secular. Um lado descreve o embrião no estágio prematuro de desenvolvimento como um "amontoado de células" e o confronta com a pessoa do recém-nascido, a quem primeiramente compete a dignidade humana no sentido estritamente moral. $O$ outro lado considera a fertilização do óvulo humano como o início relevante de um processo de desenvolvimentos já individualizado e controlado por si próprio. ${ }^{2}$

Habermas traça uma análise densa diante das implicações do uso das novas tecnologias de intervenção que visam modificar a herança genética dos seres humanos. Ele reconhece que não é possível recorrer com unanimidade a uma justificativa moral que estabeleça o estágio de início da vida humana pré-pessoal em uma sociedade secular de concepção pós-metafísica. Essa problemática permeia o debate acerca da ética da espécie referente à identidade da espécie humana. Assim, para Habermas (2010, p. 45), no campo da moral, tanto a posição do naturalismo científico, com suas proposições fundamentais e ontológicas, quanto as proposições metafísicas ou religiosas, não conseguem consenso em um argumento conclusivo. Poder-se-ia resolver esse problema, afirma Habermas (2010, p. 45, grifo do autor), "[...] apenas com base numa descrição ideologicamente marcada dos fatos, que permanecem razoavelmente discutíveis nas sociedades pluralistas." Ambos os lados não conseguem ultrapassar o campo das questões morais comuns na tentativa de traçar um limite relevante sobre o fato de estabelecerem um início absoluto, conclui ele. Procura-se, pois, afastar quaisquer posições arraigadas exclusivamente ou a uma sacralidade da vida humana ou a uma discussão biológica. Sinaliza Habermas (2010, p. 46) que:

No entanto, a substância normativa da necessidade de proteger a vida humana pré-pessoal não encontra uma expressão racionalmente aceitável para todos os cidadãos nem na linguagem objetivante do empirismo, nem na da religião. Por fim, na discussão normativa de uma esfera pública democrática importam apenas as proposições morais em sentido estrito. Somente as proposições ideologicamente neutras sobre aquilo que é igualmente bom para todos podem ter a pretensão de ser aceitáveis para todos por boas razões.

Nessa discussão é importante estabelecer a distinção entre dignidade humana e dignidade da vida humana. Habermas (2010, p. 47-51) pretende demonstrar que a dignidade humana representa uma condição moral e jurídica, a qual faz sentido a partir da ligação com uma comunidade composta por seres morais, dotados de relações simétricas e responsáveis, os quais possuem acordos

\footnotetext{
ligada ao sexo). O processo requer a criação de um embrião fora do corpo pela técnica da fertilização in vitro. Cerca de dois a três dias após a fertilização, quando o embrião consiste cerca de seis a dez células, uma ou duas células são removidas do embrião, processo que parece ser compatível com a continuidade do desenvolvimento embrionário. $O$ material genético dessas células é então examinado: em nível cromossômico, se a questão é estabelecer o sexo para doenças ligadas ao X ou identificar anormalidades cromossômicas; ou em nível da sequência do DNA se for, por exemplo, um defeito monogênico."

2 Segundo Habermas (2010, p. 44), "[...] ambos os lados parecem não se dar conta de que algo pode ser considerado como 'indisponível', ainda que, nos termos da constituição, é portador de direitos fundamentais inalienáveis. 'Indisponível' não é apenas aquilo que a dignidade humana tem. Nossa disponibilidade humana pode ser privada de alguma coisa por bons motivos morais, sem por isso ser 'intangível' no sentido dos direitos fundamentais em vigor de forma irrestrita e absoluta."
} 
estabelecidos em um mesmo contexto normativo. Já a dignidade da vida humana antecede a construção dos contextos morais, pois ela remonta a estágios pré-pessoais, nos quais os indivíduos ainda estão em formação. Continua Habermas (2010, p. 47), afirmando que a primeira está circunscrita em um espaço de relação intersubjetiva de reconhecimento recíproco e igualitário entre as pessoas; a segunda, porém, dirige-se a uma segunda pessoa que "[...] também conserva um valor integral para a totalidade de uma forma de vida eticamente constituída." (HABERMAS, 2010, p. 51).

A comunidade de seres morais, na questão específica sobre as proposições aqui discutidas, refere-se ao fato de que a dignidade humana não é algo que se possa prover a priori, isto é, uma concepção metafísica. Devem-se lembrar, aqui, duas tradições para a exemplificação do que se está tratando. A tradição teológica bíblica, que concebe o homem a partir da linguagem da Revelação, fundamenta a dignidade da pessoa humana a partir de sua criação à imagem e semelhança de Deus. Desde a concepção até o nascimento, a imagem e a semelhança divinas estão presentes em cada pessoa, e, por isso, o exercício da vida moral atesta em respeitar a dignidade da pessoa. Por sua vez, Kant (2009) procura não mais fundamentar a dignidade da pessoa em algo externo, em tradições, na vontade de Deus ou em necessidades, mas na autonomia do sujeito, na razão. Ele afirma que os seres humanos possuem um valor intrínseco inviolável e precisam sempre ser tratados como fim. Trata-se da formulação importante do imperativo categórico kantiano, princípio moral do qual devem derivar as obrigações e responsabilidades dos seres humanos. Kant (2009, grifo do autor), na Fundamentação da metafísica dos costumes, destaca o caráter racional do ser humano e delineia o imperativo princípio da vontade racional: "Age de tal maneira que tomes a humanidade, tanto em tua pessoa, quanto na pessoa de qualquer outro, sempre ao mesmo tempo como fim, nunca meramente como meio." (FMC AK 429) (KANT, 2009, grifo do autor). Assim, o valor ético da humanidade encontraria um valor absoluto em si mesmo, isto é, um valor incondicional e supremo, universalmente válido.

Habermas (2010, p. 48) procura identificar em sua abordagem como e em que medida a dignidade humana é construída a partir e pelas relações intersubjetivas na rede de relações legitimamente reconhecidas. A publicidade da razão no interior do debate normativo da esfera pública tem sua sede (HABERMAS, 2010, p. 53) em uma forma de vida linguística estruturada. Essa comunidade moral é constituída por sujeitos livres e iguais de direitos com capacidade de imputação e de levar uma vida autônoma (HABERMAS, 2010, p. 110). Nesse sentido, continua Habermas (2010, p. 50), a comunidade assim instituída admite uma "[...] rede simbólica das relações de reconhecimento recíprocas entre pessoas que visam à comunicação", ou seja, o recém-nascido passa a se identificar como pessoa e membro da comunidade moral a partir dessa forma simbolicamente produzida. É plausível supor que, no caso de uma pessoa comprometida com a sua naturalidade genética, ou seja, que foi submetida a uma intervenção médica, poderá afetar, por assim dizer, a consciência de sua autonomia, uma vez que a intervenção genética altera suas características e a faz se sentir determinada por outrem.

Uma vez que o ser humano nasce "incompleto", no sentido biológico, e passa a vida dependendo do auxílio da atenção e do reconhecimento do seu ambiente social, a imperfeição de uma individualização fruto de sequências de DNA torna-se momentaneamente visível quando tem início o processo de individualização social. Aquilo que, somente pelo nascimento, transforma o organismo numa pessoa, 
no sentido completo da palavra, é o ato socialmente individualizante de admissão no contexto público de interação de um mundo da vida partilhado intersubjetivamente [...] $\mathrm{O}$ ser geneticamente individualizado no ventre materno, enquanto exemplar de uma comunidade reprodutiva, não é absolutamente uma pessoa "já pronta". Apenas na esfera pública de uma comunidade linguística é que o ser natural se transforma ao mesmo tempo em indivíduo e em pessoa dotada de razão. (HABERMAS, 2010, p. 49, grifo do autor).

Retomando a questão supracitada, Habermas (2010) entende que o ser humano nasce incompleto biologicamente e depende do auxílio de uma série de elementos normativos, ligados à ideia de dignidade humana, isto é, à autocompreensão ética da espécie, de sujeitos livres e responsáveis. O comportamento moral deve ser entendido "[...] como uma resposta construtiva às dependências e carências decorrentes da imperfeição da estrutura orgânica e da fragilidade permanente da existência corporal." (HABERMAS, 2010, p. 47). Essa tese é central, porque, para Vilaça (2009, p. 222), a precariedade corpórea humana é entendida como característica fundamental da autocompreensão ético-existencial do indivíduo. Conforme Dias e Vilaça (2013, p. 250, grifo do autor), "[...] a corporalidade é uma condição fundamental da autocompreensão ético-existencial do indivíduo enquanto espécie, constituindo-se como um fundamento de sua visão de comportamento moral." Dessa forma, o dado empírico representa um critério para a moralidade capaz de resgatar a noção de dignidade da vida humana. $\bigcirc$ homem deixaria de se reconhecer como único autor de sua história, caso fosse manipulado geneticamente. Em outras palavras: "[...] o si mesmo individual surge apenas como o auxílio social da exteriorização e também só pode se estabilizar na rede de relações intactas de reconhecimento." (HABERMAS, 2010, p. 47-48, grifo do autor). E continua afirmando que, nesse sentido, "[...] a autonomia é, antes, uma conquista precária de existências finitas, que só conseguem 'se fortalecer' quando conscientes de sua vulnerabilidade física e de sua dependência social." A intervenção genética refere-se à própria noção de identidade do indivíduo, uma vez que o ser geneticamente manipulado até ali não é uma pessoa absolutamente pronta, pois ainda carece da interação social na comunidade linguística, na qual poderá ter um reconhecimento recíproco de pessoas que agem com autonomia. ${ }^{3}$

Segundo Feldhaus (2008, p. 544), há uma preocupação essencial em Habermas que evidencia a falta de consideração por parte da intervenção genética à dignidade da vida humana. Feldhaus (2008, p. 544) continua afirmando que Habermas:

Atribuindo dignidade à vida humana do embrião, todavia, ele não está retomando à antiga questão do estatuto do embrião, pois a abordagem habermasiana parte da impossibilidade de resolvê-la. A abordagem habermasiana se preocupa com os fundamentos naturais e antropológicos da autonomia e da liberdade ética.

Nessa perspectiva, em Habermas, quando se olha para a vida humana pré-pessoa, toca-se no autoentendimento como membro da espécie humana. Por conseguinte, Habermas advoga uma mesma base de identidade dos seres humanos como espécie compartilhada por toda a humanida-

\footnotetext{
3 Ainda na concepção de Habermas (2010, p. 49): "[...] o ser geneticamente individualizado no ventre materno, enquanto exemplar de uma comunidade reprodutiva, não é absolutamente uma pessoa 'já pronta'. Apenas na esfera pública de uma comunidade linguística é que o ser natural se transforma ao mesmo tempo em indivíduo e em pessoa dotada de razão."
} 
de. $\bigcirc$ autor pretende resguardar intacta a herança genética isenta de intervenções artificiais, pois a autocompreensão de sujeitos que agem de forma livre e igual depende, fundamentalmente, da compreensão antropológica como membros da espécie (HABERMAS, 2010, p. 55). A dignidade humana está intrinsecamente relacionada ao modo a partir do qual o ser humano se compreende como membro da espécie humana, determinando "[...] se um embrião tem ou não direitos constitucionais assegurados, como pessoa, pois é preciso saber se ele já é membro da espécie e como é membro da espécie." (DUTRA, 2005, p. 259). Desse modo, na concepção de Habermas, a forma de lidar com a vida humana pré-pessoal gera questões de uma dimensão totalmente diferente, ou seja,

Elas aludem não a esta ou àquela diferença na variedade das formas de vida cultural, mas a autodescrições intuitivas, a partir das quais nos identificamos como pessoas e nos distinguimos de outros seres vivos - portanto, nossa autocompreensão enquanto seres da espécie. (HABERMAS, 2010, p. 55).

A questão habermasiana de como o ser humano quer compreender-se como espécie humana encontra, na diversidade cultural, diversas imagens que, no decorrer da história, formaram-se sobre o homem. O desdobramento da pergunta "o que é o homem?" suscita dificuldades, na atualidade, em encontrar uma linha conceitual que unifique as múltiplas visões que descrevem as categorias fundamentais sobre o ser homem. Trata-se de uma pergunta tão abrangente que requer um novo nível de análise diante do desenvolvimento da tecnologia genética, que afeta significativamente a imagem que o ser humano construiu de si mesmo. O ser humano se pergunta sobre si mesmo e acerca daquilo que o constitui a partir de certas visões ou enquadramentos, seja no campo da ciência, da metafísica, seja da religião, pertencendo a um sistema de interpretações que representa um contexto antropológico denso e plural. De acordo com Habermas (2010, p. 57), nas sociedades pluralistas, sob as condições pós-metafísicas, as interpretações em torno de uma autocompreensão ética da espécie, articulada em determinadas tradições e formas de vida, não permitem que convirjam, de certo modo, para uma moral válida para todos e em todas e quaisquer situações. Conforme Pinzani (2005, p. 165), "[...] por ser uma sociedade pluralista, ela não dispõe de concepções éticas compartilhadas e já não pode apelar para a tradição na tentativa de justificar normas." Assim, Habermas entende que há a necessidade de uma antropologia de base que seja adequada à moral, a fim de haver uma conexão entre autocompreensão moral e considerações éticas de espécie.

Para Pinzani (2005), Habermas utiliza a distinção entre ética e moral para aprofundar a discussão, não supondo uma divisão radical entre ética e moralidade, porém, propõe-se criar uma ponte entre a dimensão ética e a dimensão universal da moral. Nessa medida, entende-se que esta possui argumentos válidos universalmente e independem do contexto social e histórico, enquanto aquela está ligada mais diretamente aos valores que certa comunidade possui (PINZANI, 2005, p. 363). No interior das discussões acerca da prática da eugenia liberal, Habermas está disposto a ir além da esfera privada dos indivíduos particulares, a fim de promover uma universalidade de reconhecimento também no âmbito ético, quer dizer, repensar as questões éticas além do que cada sujeito possui como condição para a formação das leis morais. Por esse motivo, há de se pensar em uma ética da espécie humana a partir do paradigma da intersubjetividade, em que os indivíduos possam 
construir seus argumentos, considerando sua história de vida e sua relação com o espaço público. Para Habermas (2010, p. 7, grifo do autor), "[...] as convicções morais só condicionam efetivamente a vontade quando se encontram inseridas numa autocompreensão ética, que coloca a preocupação com o próprio estar a serviço do interesse pela justiça." Assim, à medida que há uma construção não restrita apenas àquilo que o sujeito particular tem consigo mesmo, pode-se, no âmbito intersubjetivo, nas argumentações prático-morais, construir uma moral responsável.

Habermas (2010, p. 6) afirma que a ética deve ser tomada "[...] no sentido clássico de uma doutrina da vida correta." Pois, as questões éticas que se ocupam do bem-estar dos indivíduos remetem a questões de identidade, e, de acordo com Habermas (2010, p. 6), não há, para elas, "[...] nenhuma resposta que não dependa do respectivo contexto." Isso significa que essa questão "[...] pressupõe uma certa autocompreensão de si como sujeito moral e, mais em geral, uma autocompreensão ética da espécie." (PINZANI, 2005, p. 364).

Para tanto, o programa da eugenia liberal parece não considerar que a manipulação da composição do genoma humano, conforme Habermas (2010, p. 60), "[...] poderia afetar nossa autocompreensão ética da espécie de tal forma, que também a consciência moral seria afetada." Por isso, Habermas considera que é necessária uma autocompreensão ética da espécie, compartilhada por todas as pessoas morais, da qual dependeria, fundamentalmente, o fato de ainda continuarmos a nos compreender como autores únicos e indivisos de nossa história de vida e podermos nos reconhecer mutuamente como seres que agem autonomamente.

\section{Futuro da natureza humana}

Os avanços da engenharia genética e a aplicação dessa tecnologia aos seres humanos suscitam, segundo Fukuyama (2003, p. 85), "[...] com todas as implicações morais que essa palavra carrega, e em última análise a possibilidade da modificação da natureza humana." A preocupação, provocada pelo surgimento da biotecnologia, é de como será compreendida a natureza humana, pois ela, segundo algumas leituras e prognósticos, estaria radicalmente ameaçada na medida em que o domínio das bases genéticas permitiria aos cientistas transformá-la, podendo, inclusive, ameaçar as próprias relações democráticas. Habermas, em sua argumentação, busca mostrar a importância da proteção da natureza humana como condição para os seres humanos se compreenderem enquanto livres e responsáveis.

Mas o que é e qual é precisamente a natureza humana que Habermas está preocupado em proteger? Habermas não poderia ser identificado como um defensor da sacralização da natureza humana? Conforme Dias e Vilaça (2013, p. 234), Habermas assume uma posição bioconservadora que demonstra a sua inquietação com o impacto que pode ser gerado com o melhoramento médico sobre a natureza humana. Isso se torna claro, porque, de acordo com Habermas, a natureza humana fundamentaria a dignidade, a liberdade e a autonomia, além de cumprir a simetria das relações sociais e a autocompreensão normativa enquanto seres de uma espécie. Nessa perspectiva, as intervenções genéticas de aperfeiçoamento seriam moralmente condenáveis, uma vez que elas poderiam alterar 
ou, até mesmo, destruir a natureza humana, ou seja, elas poderiam abalar a base a partir da qual e sobre a qual os valores normativos seriam determinados e construídos.

A discussão sobre o que caracteriza a natureza humana é um clássico problema filosófico que transita por vários campos do saber. A importância atribuída ao florescimento dessa questão desenvolve no decorrer da história perguntas sobre o que pode ser promovido e combatido na natureza humana, instigando a reflexão filosófica por parte de uma infinidade de pensadores que partem de uma acepção de natureza humana, a fim de formularem suas teorias. A reflexão sobre o que é a natureza humana permanece no centro das mais variadas interrogações da cultura. E com essa pergunta emerge a singularidade do próprio ser humano que é capaz de se interrogar reflexivamente sobre si mesmo em relação ao seu mundo exterior. Nesse sentido, o problema atual sobre o direcionamento se a natureza humana pode ser alvo ou não da manipulação genética por conta do desenvolvimento da biotecnociência tornou ainda mais difícil compreender a inquietação que essa pergunta gera nos debates contemporâneos.

Os avanços da engenharia genética e as formas de intervenção médica poderão ocasionar uma mudança nos limites entre o acaso e a livre decisão. Essas intervenções minam a fronteira entre aquilo que por natureza somos (uma espécie de loteria natural) e aquilo que nos damos a nós mesmos (por livre escolha e autodeterminação). Habermas acredita que a modificação genética gera um deslocamento grave, porque ela pode afetar a consciência da autonomia de outrem. A contingência que marca a formação de nossa constituição genética é entendida como fundamental para nossas imputações morais. Em outras palavras, resguardar intacta a herança genética significa proteger certa autocompreensão normativa de sujeitos livres e responsáveis. Habermas intende mostrar como a precariedade e a vulnerabilidade biológica são fundamentais para a autocompreensão ético-existencial do indivíduo enquanto espécie, constituindo o seu comportamento moral. Nessa perspectiva, de acordo com Kersting (2003), o conceito de natureza humana evidencia a própria fundamentação dos direitos humanos na medida em que a vulnerabilidade humana marcada pela ordem natural do ser humano frágil e precário representa um critério para o endentimento da moralidade. É elucitativa a citação a seguir:

Portanto, só mediante a estrita consider ação da natureza humana do ser humano se chega ao cerne do conceito de direitos humanos. Na igualdade classificatória biológica, anterior a toda a diferenciação ideológica e auto-interpretação cultural, se encontra o oposto do igualitarismo normativo dos direitos humanos. O único ser humano relevante em termos de fundamentação teórica dos direitos humanos é um ser finito, mortal, vulnerável e capaz de sofrer; a proteção dos direitos humanos baseia-se na simples evidência da vulnerabilidade humana e na preferencialidade, não menos evidente, de um estado de ausência de assassinato e homícidio, dor e violência, tortura, miséria e fome, opressão e exploração. (KERSTING, 2003, p. 94, grifo do autor).

Kersting (2005), no capítulo intitulado Eugenia liberal, do livro Liberdade e liberalismo, faz uma análise crítica muito interessante sobre o argumento de Habermas, que atenta sobre os efeitos da engenharia genética em nossa autocompreensão normativa. Para Kersting (2005, p. 96), Habermas tem um "calcanhar de aquiles" consequencialista. Quer dizer, ele "[...] precisa demonstrar a existência de dependências causais, mas só pode apoiar-se em suposições prognósticas questionáveis 
e em estimativas incertas das consequências." Segundo ele, seria preciso mostrar com base na experiência se a intervenção genética mina a igualdade moral das pessoas, restringindo a sua autonomia e ameançando seu projeto racional de vida. Nesse sentido, para Kersting (2005, p. 98), o ponto da argumentação habermasiana não se concentra apenas no fato de que a melhoria é genética, porque "[...] toda dotação genética, também aquela proporcionada pela natureza, apresenta uma limitação, abrindo determinadas possibilidades de ação, mas excluindo outras." Ainda, com Kersting, a questão aqui referida está nos efeitos que a programação genética pode acarretar com a prática eugênica, os quais se expressam exclusivamente nas intenções na constituição genética dos filhos como incremento da autonomia dos pais.

Na concepção de Kersting (2005, p. 99), para Habermas, referente à escolha de determinadas características genéticas de um indivíduo, “[...] a eugenia liberal é condenável, não porque signifique uma disposição dos fundamentos genéticos de nossa existência corporal por outrem, mas sim porque ele é de opinião de que não há preferências eugênicas universais." Quer dizer, em uma sociedade plural há dificuldade de se obter um consenso, no que se refere ao que se deve evitar ou permitir em uma intervenção genética. Nesse sentido, a partir de Kersting (2005), essa discrepância pode ser analisada quando se procura refletir acerca da otimização da tecnologia genética terapêutica e da de aperfeiçoamento. Habermas faz uma distinção moral, relativa ao tipo de intervenção genética; no caso da primeira (eugenia negativa), haveria poucas objeções morais a serem feitas, porém na segunda (eugenia positiva), parece que se estaria percorrendo um terreno perigoso, pois estaríamos dispondo da vida humana para propósitos de seleção. A pergunta inquietante permanece: seria possível estabelecer um limite para evitar o problema do alcance dos dois tipos, e quais os critérios para garantir o "tipo bom" de intervenção genética, em uma sociedade pluralista? Habermas parece não deixar claro esse ponto. Contudo, no caso da intervenção terapêutica (eugenia negativa), ele explica: a decisão dos pais e dos médicos para a cura de uma doença poderia ser coberta por um tipo de assentimento dos filhos, ou seja, há de se pressupor um consentimento presumido a posteriori. Entretanto, no caso da intervenção relativa ao aperfeiçoamento (eugenia positiva), Habermas problematiza em termos de uma autocompreensão normativa de espécie, fazendo surgir outra questão (KERSTING, 2005, p. 101, grifo do autor): "Quem, depois de ter sido esclarecido acerca de seu designer genético, acusaria, mais tarde, seus pais por não o terem deixado em seu estado natural de escassez cognitiva?" Ou seja, como Habermas pode concluir que um indivíduo manipulado geneticamente para fins de aperfeiçoamento poderá não consentir com sua herança genética? Até que ponto o argumento da autonomia possibilita a Habermas a validade de sua estratégia contra a programação de um genoma?

Percebe-se, aqui, claramente, a posição de Habermas. Ele parte do pressuposto de que a intervenção de aperfeiçoamento pode afetar a autonomia do indivíduo, tendo de ser, por conseguinte, essa técnica regulamentada. Todavia, conforme Kersting (2005), não há possibilidade de garantir, de antemão, a postura do indivíduo manipulado quanto à sua autocompreensão ser distorcida ou não, isto é, se o indivíduo vai se compreender menos livre simplesmente pelo fato de seu patrimônio genético ter sido influenciado e gerido por outros. Kersting parece estar convencido de que a condenação habermasiana à eugenia liberal, com base na ética da autonomia, ainda não é convincente. Com efei- 
to, pode-se dizer que Habermas, mesmo não podendo justificar nitidamente esse ponto, permanece cauteloso diante dos efeitos da manipulação genética, sem ignorar a possibilidade de o indivíduo ser afetado em sua autonomia com esse tipo de intervenções.

O tema eugenia liberal é central em Habermas e demonstra a sua preocupação com as pesquisas biogenéticas orientadas pelas premissas do Estado liberal. Ele não adota uma atitude de oposição diante do desenvolvimento científico. No entanto, ele tomaria uma posição contrária, caso o uso dessa tecnologia não fosse regulamentada e viesse a alterar a nossa autocompreensão normativa. Para Habermas, o Estado liberal, alinhado e calcado sob a autonomia de escolha dos indivíduos, que intervém no patrimônio genético de outrem, sem uma regulamentação específica a respeito, corre o risco de ir ao encontro dos interesses motivados pela ótica do mercado. É pertinente ressaltar que, em se tratando do tema eugenia, os fatores do mercado podem influenciar diretamente as decisões dos indivíduos. Nesse ínterim, o que vem a ser desvelador para Habermas é que a maioria das técnicas, as quais tinham por objetivo até então a melhoria da saúde e o prolongamento da vida do homem, abriu novas iminentes possibilidades para manipulações, as quais, em vez de objetivarem apenas fins curativos, possibilitariam também meios de aperfeiçoamentos genéticos. Habermas parece entender que um dos principais problemas da intervenção gênica se relaciona ao fato de certas vidas humanas serem gestadas à luz de certas condições, no mínimo, suspeitas, complexas e também controversas. A manipulação genética aplicada à medicina reprodutiva poderia estar norteada pelos imperativos sistêmicos do mercado em que as pessoas seriam consumidores e clientes de produtos biotécnicos. Desse modo, dependendo apenas de os pais tomarem a decisão, por exemplo, quanto à fertilização in vitro e à constituição genética de seus filhos, poder-se-ia inferir que motivados pela lógica de mercado, a possibilidade de uma eugenia não pareceria tão distante.

A análise feita por Habermas é muito pertinente, pois quando se fala em eugenia, os fatores do mercado podem influenciar significativamente a escolha dos pais no patrimônio genético de seus filhos. Mas, por que toda essa preocupação de Habermas com uma possível eugenia? Qual é o problema? A eugenia não é uma tendência já presente na sociedade atual? Como não é o objetivo dessa reflexão entrar nos meandros do temor que rodeia Habermas acerca do tema da eugenia e sua experiência com o programa eugênico do Nazismo, na Alemanha percebe-se que a eugenia está presente nas relações e nos comportamentos das pessoas de uma forma diferente daquela que poderia se originar com a engenharia genética. Pinzani (2005) procura identificar como, por exemplo, a moda é a expressão de uma tentativa que busca homogeneizar a aparência do comportamento, resultando nos traços culturais e costumes de vida. $\bigcirc$ recurso às técnicas eugênicas de aperfeiçoamento está ligado à lógica de sempre mais buscar um corpo mais belo, mais jovem e uma imagem estética mais perfeita. Nas sociedades contemporâneas há uma crescente preocupação com o corpo e um excessivo consumo de cosméticos. Nesse sentido, são os filmes, a televisão, a publicidade, as revistas, etc. que ajudam a criar novos padrões de aparência e beleza, difundindo novos valores na cultura e projetando estilos de vida para o mundo inteiro.

Obviamente, a tendência aqui discutida acerca da eugenia, no decorrer deste estudo, com a introdução das técnicas genéticas positivas no ser humano, atualmente ainda está em processo de 
desenvolvimento, mas qualquer passo nessa direção é um avanço muito significativo para a ciência. Pode-se perceber, por exemplo, como as descobertas da tecnologia genética repercutiram no cinema, como no cenário descrito no filme Gattaca (1997), em que, em um futuro não tão distante, seres humanos se dividirão em duas classes: os primeiros serão os escolhidos geneticamente em laboratórios para serem inteligentes e criativos; os demais serão pessoas concebidas biologicamente que ficam à mercê da própria natureza. $\bigcirc$ filme mostra basicamente como a manipulação genética geraria um critério de distinção entre as classes, entre as mais e as menos favorecidas ao acesso à tecnologia.

Outro elemento importante nesta pesquisa diz respeito a algumas críticas a Habermas em relação à sua obra $O$ futuro da natureza humana. As críticas desenvolvidas por Fenton (2006) em Liberal Eugenics \& Human Nature: Against Habermas asseveram que Habermas estaria assumindo a posição de um defensor da ressacralização da natureza humana, considerando-a como algo de sagrado, e para a qual as técnicas de intervenção genética seriam uma ameaça. De acordo com a leitura de Feldhaus (2011, p. 53), Fenton discorda de quatro argumentos defendidos por Habermas: "1) A eugenia liberal ameaça a dignidade humana e os fundamentos da comunidade moral como consequência disso; 2) ela altera as relações na comunidade moral; 3) ela mina a igualdade moral; e, finalmente, 4) ela mina a liberdade individual e a autonomia."

Ainda de acordo com a análise de Feldhaus (2011, p. 53), Fenton reconhece a sofisticação da argumentação habermasiana contra a eugenia liberal. Entretanto, segundo Fenton, Habermas estaria considerando a natureza humana como algo sagrado, e, consequentemente, poder-se-ia supor que ele pretenderia construir sua argumentação baseada em uma natureza humana estritamente valiosa recorrendo a uma verdade de cunho metafísico. E isso estaria totalmente controverso com a sua concepção pós-metafísica na sociedade secular. Nesse sentido, afirma Feldhaus (2011, p. 54) a favor de Habermas e contra Fenton:

[...] essa intepretação é claramente equivocada, dado que em nenhum momento Habermas enuncia ou evidencia a intenção de mostrar tal tese e o que ele parece estar afirmando é que entre as concepções de natureza humana possíveis, aquela em que os seres humanos podem se compreender como iguais e livres e atribuírem-se mutuamente responsabilidade por suas ações é a que deve ser protegida.

Portanto, o ponto central de Habermas é assegurar a liberdade individual e a participação na comunidade moral protegendo uma forma de autocompreensão normativa. Feldhaus (2011, p. 54) certifica que Fenton faz uma leitura de Habermas como tentando "derivar conclusões normativas de fatos", ou seja, manter intacta a base orgânica como condição para sermos morais. Assim, a intervenção genética seria um obstáculo para admitir relações de igualdade entre os seres humanos. Nesse sentido, Fenton intenta identificar Habermas:

[...] como um defensor da sacralização da natureza humana e juntamente com isso ressalta reiteradamente que a natureza humana não tem status normativo, entretanto Habermas claramente opõe-se a qualquer tipo de estratégia argumentativa que busca derivar valores de fatos, inclusive quando aborda temas de bioética como a clonagem. (FELDHAUS, 2011, p. 54). 
É também muito elucidativa a citação de Kersting (2005, p. 92-93) acerca da argumentação habermasiana quanto à importância da indisponibilidade genética e seu suporte filosófico moral:

Habermas não recorre nem à doutrina ontológico-axiológica da sacralidade da vida humana, nem à datação do predicado de dignidade humana no instante da concepção. As concepções de fundamentação metafísico-regressiva da ontologia e da religião não podem reivindicar reconhecimento racional numa sociedade pluralista moderna. O pluralismo obriga os discursos morais à neutralidade cosmovisiva. Eles precisam partir de premissas que abram uma perspectiva de validade geral e possam enfocar aquilo que é igualmente bom para todos independentemente de todas as diferenças religiosas e éticas existentes.

Uma das preocupações de Habermas não é tornar sagrada a natureza, como algo já fixado e estável, pois conforme Feldhaus, o autor baseia-se com lealdade a uma concepção de moralidade pós-metafísica. Portanto, o que está em questão é "[...] o pano de fundo historicamente precário e socioculturalmente contingente da moralidade tal como ela é entendida atualmente." (FELDHAUS, 2011, p. 55). Habermas está preocupado com os efeitos da engenharia genética na forma como nos comportamos moralmente. A eugenia liberal poderia solapar nossa moral convencional e levar a um vácuo moral. Assim, a abordagem habermasiana procura identificar aquilo que há de inconsistente com o programa da eugenia liberal, mostrando uma contradição interna que particularmente pode ferir as relações de igualdade entre as pessoas, pois a eugenia liberal pode limitar a liberdade dos futuros indivíduos. $\bigcirc$ direito à liberdade reprodutiva dos pais incorreria na violação do direito à liberdade de os filhos empreenderem seu próprio projeto de vida. Para tanto, trata-se de uma concepção de natureza pós-metafísica no que se refere à contingência da base genética do ser humano. Sinaliza, pois, Habermas (2010, p. 118):

Com efeito, ela não parte da suposição de que a tecnicização da "natureza humana" representa algo como uma transgressão de limites naturais. A crítica é válida independentemente da ideia de uma ordem jusnatural ou ontológica, que poderia ser "transgredida" de maneira criminosa.

O desenvolvimento da posição habermasiana na tentativa de uma moralização da natureza humana conta com a discussão acerca dos indicadores éticos da espécie, "[...] enquanto não quisermos recorrer às garantias falaciosas da metafísica." (HABERMAS, 2010, p. 126). Ainda, segundo o autor, "[...] nem todas as concepções sobre a ética da espécie humana harmonizam-se em igual medida com nossa autocompreensão enquanto pessoas moralmente responsáveis." (HABERMAS, 2010, p. 126, grifo do autor). Habermas compreende a espécie humana a partir do conhecimento e da reflexão de fatos antropológicos profundos em paralelo à reflexão da forma pela qual os seres humanos venham a se compreender. Por isso, a perspectiva da instrumentalização da natureza humana com a engenharia genética põe em xeque o status moral das futuras gerações submetidas a essa intervenção. Portanto, há importância de assegurar certa autocompreensão normativa como referência para a comunidade moral, pois, para Habermas (2010, p. 126), "[...] a vida no vácuo moral, numa forma de vida que nem sequer conheceria o cinismo moral, não valeria a pena ser vivida." Não obstante 
Dworkin tenha posições distintas e até divergentes em relação às de Habermas, ele reflete acerca dessa questão e afirma:

O terror que muitos de nós sentimos ao pensar na engenharia genética não é um medo do que está errado; pelo contrário, é o medo de perder o pulso sobre o que está errado [...] Todavia temos o direito de estar apreensivos que nossas convicções arraigadas, muitas delas, venham a ser solapadas, que venhamos a sofrer uma espécie de queda-livre moral, que tenhamos que pensar novamente contra um novo pano de fundo e com resultados incertos. (DWORKIN, 2005, p. 635).

Diante desse tema tão inquietante e importante, nota-se como, em e com Habermas, os princípios morais, amplamente reconhecidos na modernidade, como a liberdade e a igualdade, correm o risco de serem solapados pela engenharia genética. Habermas está procurando tornar estável a moral em uma autocompreensão ética da espécie, para que se possa, ao menos, "[...] tomar consciência dessa moral e de seus pressupostos, antes de nos habituarmos à revisão furtiva daquilo que, até agora, fazia com que a consciência da autonomia e a igualdade entre as gerações fossem pensadas como evidentes." (HABERMAS, 2010, p. 128).

A partir da argumentação supracitada, abre-se a possibilidade de pensar que na abordagem habermasiana não é possível compreender a natureza humana apenas como algo natural, mas, também, a partir das relações que se estruturam ativamente entre os indivíduos nas relações sociais. Ou seja, ela estaria vinculada à ideia da ação deles dentro de um contexto relacional intersubjetivo. A natureza humana está ligada não apenas ao biológico, que molda os seus limites, mas é investida, também, da própria maneira com que os seres humanos guiam as suas normas e define-os enquanto tal na medida em que serve de referência para a sua autocompreensão normativa. $\bigcirc$ apelo de Habermas a um controle do Estado sobre o desenvolvimento das pesquisas atuais e futuras, provenientes das biotecnologias aplicadas ao ser humano, deve-se ao fato da possibilidade da ameaça iminente de poder modificar a natureza humana e com ela as noções normativas construídas até então.

Mas o que deveria ter de errado em alterar a natureza humana uma vez que poderíamos buscar o seu aperfeiçoamento, libertando-nos de nossos limites biológicos? O que haveria de errado nisso? Atualmente, essa pode ser tida como a mais polêmica questão existente no debate bioético na área da engenharia genética, pois demonstra a preocupação com o impacto dos melhoramentos técnicos e científicos sobre a natureza humana. Conforme Dias e Vilaça (2013, p. 240), os transumanistas, que apontam para o promissor melhoramento genético e acreditam na hipótese do estágio pós-humano, inserem-se na discussão acerca da natureza humana, problematizando-a em três pontos: "(1) a ideia de que é algo essencial, fixo e universal; (2) que absolutamente boa; e (3) que, como serve de firme fundamento da moral, alterá-la representaria o solapamento dos nossos valores e da moralidade em si." Há autores que concordam com essas objeções e se colocam favoráveis ao considerarem a natureza humana como algo não em si, pois não há uma essência que seja capaz de explicar o que ela é. A natureza humana, de acordo com essa concepção, é multifacetada e não poderia ter qualquer fundamento, pois se baseia na expressão de certos valores a despeito de um contexto histórico situado (DIAS; VILAÇA, 2013, p. 232). Nesse sentido, segundo Dias e Vilaça (2013, p. 240), há autores que concordam existir uma natureza humana, mas procuram defender outra concepção 
ou afirmam que "[...] ela é apenas um ponto de partida, mas não de chegada." Ora, assumindo esses pontos, há motivos para ecoar o tema da pós-humanidade, de uma nova era da humanidade em que todos poderão ultrapassar os limites da condição humana.

A fim de considerar esses pontos e a posição de Habermas contra a eugenia liberal, identificou-se a sua posição perante a moralização da natureza humana, no sentido de considerar certa autocompreensão normativa da espécie de autonomia e de responsabilidade diante de nossas ações. Assim, conforme a afirmação de Feldhaus (2011, p. 56):

[...] a natureza humana tal como a compreendemos no sentido moderno é valiosa ou precisa ser protegida não por ser valiosa em si mesma ou por recorrer a uma visão ontológica do mundo, mas antes por ser a única compatível com uma moral moderna, em que autonomia e liberdade são elementos essenciais.

\section{Considerações Finais}

À luz dos pontos anteriormente trabalhados, ficam evidenciados os elementos presentes na argumentação habermasiana, os quais apontam para a necessidade de regulamentação da técnica genética. Conforme Habermas (2010, p. 30-34), a forma de intervir no genoma humano "[...] transforma-se numa questão de legislação política." E ele continua afirmando que "[...] aquilo que se tornou tecnicamente disponível por meio da ciência deve voltar a ser normativamente indisponível por meio do controle moral." A pesquisa biogenética, que adquire proteção com o Estado constitucional liberal, suscita questões referentes à ética de espécie, uma vez que pode afetar nossa autocompreensão normativa de seres que agem de forma autônoma, livre e responsável. Faz-se urgente, então, perceber como Habermas empreende algumas pressuposições que evidenciam a incompatibilidade de alguns tipos de intervenção genética com a eugenia liberal. Ele sustenta a regulação das intervenções terapêuticas (eugenia negativa) e a proibição das intervenções de aperfeiçoamento (eugenia positiva). Por certo, pode-se entender que a manipulação genética, à luz da compreensão habermasiana "[...] é um ataque às representações do direito e da moral, os fundamentos normativos e incontornáveis da integração social." (HABERMAS, 2010, p. 37). O propósito do autor revela a sua preocupação com o uso da biotecnologia genética em razão de ela estar envolvida na atitude subjacente à eugenia liberal que não reconhece o limite entre as intervenções terapêuticas e as de aperfeiçoamento.

Para finalizar, cabe ressaltar a importância da discussão e debate acerca da eugenia, seja ela na perspectiva negativa, seja na positiva. Trata-se de pesquisar com seriedade os argumentos a respeito desse relevante tema que encerra questões de bioética, de biodireito e de biopolítica. Em outras palavras, defende-se a ideia de que nenhuma área do saber pode estar alheia a esse tão eloquente tema, por conta de suas referência e implicação diretas à compreensão do ser humano no mundo, neste início de século XXI, eminentemente, preconizado pela ciência e pela tecnologia. Não basta se ater à discussão se a eugenia se constitui ou se constituirá em um direito ou não desta ou de futuras gerações. Trata-se, antes e muito mais, de problematizá-la e pô-la na baila das discussões em uma sociedade secularizada, a fim de não se tomarem decisões precipitadas e irresponsáveis em nome de uma tão sonhada decisão livre e autônoma. Não cabe, aqui, por conseguinte, assumir um dos lados, isto é, posicionar-se a favor 
ou contra a eugenia. Nessa perspectiva, de acordo com a reflexão trabalhada, urge a responsabilidade pela humanidade enquanto tal estar acima de quaisquer interesses de corporações e de grupos hegemônicos por conta de seu poder econômico ou manipulação sociopolítica.

\section{Referências}

DIAS, Maria Clara; VILAÇA, Murilo Mariano. Natureza humana versus aperfeiçoamento? Uma crítica aos argumentos de Habermas contra a eugenia positiva. Princípios, v. 20, n. 33, p. 227-263, 2013.

DUTRA, José Volpato. Razão e consenso em Habermas. Florianópolis: Ed. UFSC, 2005.

DWORKIN, Ronald William. A virtude soberana: a teoria e a prática da igualdade. São Paulo: Martins Fontes, 2005.

FELDHAUS, Charles. Habermas, eugenia liberal e o direito à liberdade reprodutiva. Fragmentos de Cultura, v. 18, p. 543-553, 2008.

FELDHAUS, Charles. Natureza humana, liberdade e justiça: um estudo a respeito da posição de Habermas acerca da biotécnica. Curitiba: CRV, 2011.

FELDHAUS, Charles. Teria Habermas recorrido a uma suposição Dworkiana equivocada em die Zukunft der menschlichen Natur? In: LIMA, Clóvis Ricardo Montenegro de (Org.). Mudança estrutural na esfera pública 50 anos depois. João Pessoa: Ed. UFPB, 2012. p. 301-316.

FENTON, Elizabeth. Liberal Eugenics \& Human Nature. Against Habermas. Hasting Center Report, v. 36 , i. $6,2006$.

FUKUYAMA, Francis. Nosso futuro pós-humano: consequências da revolução da biotecnologia. Rio de Janeiro: Rocco, 2003.

HABERMAS, Jürgen. O futuro da natureza humana: a caminho de uma eugenia liberal? São Paulo: Martins Fontes, 2010.

KANT, Immanuel. Fundamentação da metafísica dos costumes. São Paulo: Discurso Editorial: Barcarolla, 2009.

KERSTING, Wolfgang. Liberdade e liberalismo. Porto Alegre: Edipucrs, 2005.

KERSTING, Wolfgang. O natural e o artificial: argumentos morais e políticos contra a eugenia positiva segundo Habermas e Foucault.Ethic@, v. 4, n. 3, p.361-377, 2005.

KERSTING, Wolfgang. Universalismo e direitos humanos. Porto Alegre: Edipucrs, 2003.

PINZANI, Alessandro. O natural e o artificial: argumentos morais e políticos contra a eugenia positiva seguindo Habermas e Foucault.Ethic@, Florianópolis, v. 4, n. 3, p. 361-377, 2005.

SONG, Robert. Genética humana: fabricando o futuro. São Paulo: Loyola, 2005. 
VILAÇA, Murilo Mariano. O humano entre a natureza e seleção. Dilemas éticos no debate Sloterdijk-Habermas. Cadernos de Ética e Filosofia Politica, p. 211-231, 2009.

Data da submissão: 17 de maio de 2016 Avaliado em: 31 de maio de 2016 (AVALIADOR A) Avaliado em: 31 de maio de 2016 (AVALIADOR B) Aceito em: 21 de novembro de 2016 